\title{
Investigating the Relationship between Tax Revenues and Tax Ratios: An Empirical Research for Selected OECD Countries
}

Submitted 27/11/19, 1st revision 30/12/19, 2nd revision 15/01/20, accepted 17/02/20

\author{
Kostantinos J. Liapis ${ }^{1}$, Evangelos D. Politis ${ }^{2}$, Dimitra Ntertsou ${ }^{3}$, \\ Eleftherios I. Thalassinos ${ }^{4}$
}

\begin{abstract}
:
Purpose: Effective tax rates can have dual effect in the economic policy of a country by maintaining the state revenues in sustainable levels providing a safe net for the economic development. If taxation struggles the economy, there should be a turning point were the results of high tax rates do not have the expected results on the state revenue. The parabolic relation of Laffer curve is tested on a data set of different OECD countries.

Design/Approach/Methodology: Three different functions have been selected to test the Laffer curve starting from the fact that the relation of revenues with taxes should have a parabolic form, with the turning point to be the peak of the parabola.

Findings: The findings suggest that there exists a peak point where taxation policy is not providing the expected revenues. Results suggest that this pattern is common in several countries with different taxation regimes. The effective tax rates are different between the countries. Countries are divided into clusters with the same effective tax rates. The relation of the tax revenue and taxation rates is adjusted with the tax moral of the country.

Practical Implications: The results are compared with other possible forms of the relation of revenue and taxes with considerable importance.
\end{abstract}

Originality/Value:

Keywords: Laffer curve, taxation regimes, OECD countries.

JEL codes:

Paper type: Research study.

\footnotetext{
${ }^{1}$ Professor, Panteion University, Department of Economic and Regional Development, Greece, e-mail: konstantinos.liapis@panteion.gr.

${ }^{2}$ Lecturer, Agriculture University of Athens, MBA Food and Agriculture, Greece,e-mail:epolitis@icloud.com

${ }^{3}$ Phd. Candidate, Panteion University, Department of Economic and Regional Development, Greece, e-mail: $\underline{\text { d.ntertsou@panteion.gr }}$

${ }^{4}$ Professor, University of Piraeus, Aff. Professor University of Malta, e-mail: thalassinos@ersj.eu
} 


\section{Introduction}

One of the most well-known arguments of the supply-side economists that made the Laffer curve popular in the early 1980s is that lower tax rates would generate higher tax revenues and eventually stimulate economic activity in a spiral effect. In a previous research (Liapis and Politis, 2018) we try to investigate the existence of Laffer economic effect in property taxation, where we found that the revenue from the property income have a maximizing point and then start to decline when the taxation rate is escalating. On the other hand, property tax had a more straightforward relation with tax rates (Liapis and Galanos, 2010). This paper investigates the relationship between tax rates and the relevant tax revenues in the field of personal income taxation, corporate income taxation and taxation of dividends in the majority of OECD economies for the period 2000-2016. It concludes by presenting the similarities among tax regimes of the countries included in the research.

\section{Literature Review}

As Laffer $(2004)^{5}$ described, the basic idea behind the relationship between tax rates and tax revenues is that there exists a trade-off between two effects on tax revenue the arithmetic effect i.e., reduced tax rates yield reduced tax revenues and the economic effect i.e., tax cuts create incentives to increase output, employment and production (Liapis et al., 2012; 2014). The arithmetic effect always works in the opposite direction from the economic effect and as a result the overall effect on tax revenues is rather ambiguous. The illustration of this relationship between tax rates and revenues is a simple curve. The so called Laffer curve has an inverted $U$ shape, illustrating that when the tax rate is $0 \%$, revenue is zero. As the tax rate increases the revenue outcome raises, maximizes and declines when the tax rate reaches $100 \%$.

There has been considerable public debate on the possibility of an inverse relationship between tax rates and government revenue (Fullerton, 1981). Kiefer (1978) opposed the Laffer curve as it represented 'a gross simplification of a major portion of macro-economics into a single curved line'. He argued that the Laffer curve only took into account incentive and supply side effects, therefore ignoring demand side effects. Atkinson and Stern (1980) and Hemming and Kay (1980) stated that even if the endpoints of the Laffer curve for $0 \%$ and $100 \%$ tax rate are zero tax revenues, the general shape of the curve depends on the curve being a continuous function. Malcomson (1986), following Mirowski (1982) questioned some properties of the Laffer curve and especially its inverted $U$ shape, arguing that

\footnotetext{
${ }^{5}$ As Laffer himself describes in his article, the Laffer Curve concept was first introduced by Wanniski (1978) but the theory behind it has its origin back in the 14th century, with a more recent version written by John Maynard Keynes. Fullerton (1982), Ballard et al (1985), van Ravestein and Vijlbrief (1988) and Hsing (1996) attribute the association of higher taxes with lower government revenue to Adam Smith (1776).
} 
demand factors as well as other variables, such as the wage rate and the profits, determine the tax base. Malcomson suggested that empirical work on Laffer curve needs to use a well-established model, rich enough to capture dynamic economic forces. Agell and Persson (2001) characterized the concept of a Laffer curve effect as not self-evident in an intertemporal framework. Several empirical studies examine the existence (or not) of a Laffer curve either focusing on individual countries or on country groups such as the OECD and EU countries. Galanos et al. (2014) have investigated the tax competitiveness between EU countries with interesting results.

Canto et al. (1981) regressed for the USA the income tax revenue against the income tax rates for the period 1951-1964 and proved that there was a revenue maximizing tax rate above which revenues would decrease. Van Ravestein and Vijlbrief (1988) estimated the Laffer curve for the Netherlands for the period 1960-1985. They found that the revenue maximizing tax rate (considering the true proportion of government income being spent on benefits) was $70 \%$ while the actual rate was $67 \%$ and therefore the economy was operating on the upward-sloping portion of the Laffer curve. Hsing (1996) estimated for the USA a Laffer curve for the period 1959-1991 for the personal income tax, using a single-factor model and four specific functional forms - linear, log-log, linear-log and log-linear. Hsing confirmed the inverted Ushaped for the personal income tax while the revenue maximizing tax rate was estimated between $32.67 \%$ and $35.21 \%$.

Karas (2012) followed Hsing's methodology to model the relationship between the personal income tax rate and the relevant tax revenue for the period 1993-2010 in the Czech Republic. His results also confirmed empirically the inverted U-shape relationship between tax rates and tax revenues. He found that the historical tax rate was lower than the revenue maximizing tax rate which for personal income tax was equal to $33.13 \%$ of gross annual income. Sen et al. (2017) also empirically examined the Laffer curve for the personal income tax in Turkey for the period 1970-2015, confirming the validity of the Laffer curve hypothesis. They concluded that Turkey's personal income tax rate falls in the prohibitive range of the Laffer curve and should be lowered in order to collect more revenue. Brill and Hassett (2007) examined the existence of a corporate Laffer curve, for a panel of OECD countries over the period 1981-2005. The authors estimated the Laffer curve for the corporate tax rate and they found robust evidence for the existence of a trade-off between the corporate tax rate and corporate tax revenues.

Stuart (1981) examined the effects of the increase in the level of taxation in Sweden in the 1970s using a two-sector model. The model contained a single household which allocates labor to either taxed or untaxed uses. Stuart concluded that high taxes on labor income can have quite significant effects on the sale of labor in taxed markets when alternative untaxed uses of labor exist. Also, he concluded that the revenue maximizing tax rate was about $70 \%$, significantly lower than the $80 \%$ rate at the time of the analysis, indicating that Sweden was on the prohibitive range of the Laffer curve. Heijman and van Ophem (2005) developed a model of optimum 
taxation that takes into account a possible shift to informal economy for a number of OECD countries for the period 1988-1966. According to Heijman and van Ophem, an alternative for economic agents to becoming inactive when tax rates become too high, is to become active in the black labor economy. They estimated the willingness to pay tax in most countries and compared their actual tax rates with the tax revenue maximizing rates. The optimal marginal rate is always lower than $36 \%$.

Busato and Chiarini (2011) incorporate as well in a two sector dynamic equilibrium model tax evasion and underground activities to derive Laffer Curves for personal income and corporate income taxation for the Italian economy. They find that a Laffer curve exists with and without an underground sector, and they show that the strong impact of shadow economy on Laffer curves stems from the high elasticity of substitution between the formal and the informal sector. Vogel (2012) uses a general-equilibrium approach to capture the direct and indirect effects of tax policy measures, i.e., the effect of tax rate increases on tax revenues and the second round effects on their own or other tax bases. He extends the QUEST III model by tax avoidance and derives the revenue maximizing rates which are relatively high for corporate and personal income taxation compared to actual EU-average implicit labor and corporate tax rates. In economies where the official and the informal sector are closer substitutes the Laffer curve for labor and corporate taxation flattens.

Trabandt and Uhilg (2011) using a neoclassical growth model featuring "constant Frisch elasticity" (CFE) of labor supply, found that there is a Laffer curve with respect to both capital and labor income taxation for the US, the EU-14 and several individual EU countries. Average labor, capital and consumption tax rates in all countries lie below the peak of their Laffer Curves. Using a dynamic scoring analysis, they show that for the US model $32 \%$ of a labor tax cut and $51 \%$ of a capital tax cut are self-financing while for the EU-14 54\% of a labor tax cut and 79\% of a capital tax cut are self-financing. Kawano and Slemrod (2015) and Vokshi (2018) examine the relationship between corporate tax rates and corporate tax revenues, incorporating also in their research tax base changes, following their findings that changes to corporate tax rates often take place simultaneously with changes to the corporate tax base. They find that the relationship between corporate tax rates and corporate tax revenues is attenuated, pushing up the estimated revenuemaximizing rate.

Akgun et al. (2017) also examine the relationship between tax rates and the relevant tax revenues for personal and corporate income taxation as well as for consumption taxes for a panel of 34 OECD countries, for the period 1978-2014. They confirm the shape of the Laffer curve and they proceed by adding country-specific policies and framework conditions to examine the variation of estimated responses to tax rates. Dalamagas (1998) estimated the Laffer curve for 13 OECD countries for the period 1964-1994 and his findings question the shape of the Laffer curve. As he explains "The shape is closely associated with both the theoretical underpinnings of the crowding out hypothesis and the literature on the disincentive effects of taxation". 
Therefore, a permanent reduction of tax rates may lead to increased long-run budget deficits in high taxed economies with crowding-out characteristics. For particular economic activities with high elasticities, tax rates approach the prohibitive range sooner than they would elsewhere in the economy. The exact location of Laffer's curve depends on the supply elasticity of the factor being taxed (Ballard et al., 1985). Fullerton (1982) and Ballard et al. (1985) used a general equilibrium model and they were able to plot the relationship between labor tax rates and government revenues for the US economy, for a variety of values of the labor supply elasticity. Their results indicate that the US could conceivably be operating in the prohibitive area of the Laffer curve but the labor supply elasticity would have to be much higher for a labor tax rate cut to increase revenues.

Lindsey (1987) used cross-sectional data for the period 1980-1984 to estimate for the US the elasticity of taxable income with respect to the top marginal tax rate. He used two separate cross sections of data and a difference-in-differences method of study to create elasticities. He obtained elasticity estimates of 1.6 to 1.8 and found the greatest responsiveness to tax rate changes in high income earners. He showed that the US is on the prohibitive side of the Laffer curve during the time period because the tax cuts are associated with an increase in tax revenue. Feldstein (1995) studied the same group of individuals before and after the US Tax Reform Act of 1986 to estimate the elasticity of taxable income with respect to the marginal tax rate for the US. He used a difference-in-differences calculation similar to Lindsey's, except that he used panel data and not cross sectional data. He obtained elasticity estimates of 1.04 to 3.05 and similar to Lindsey's results he also found the greatest responsiveness in high income earners. He as well pointed out that the US was on the right side of the Laffer Curve during the time period under study.

Goolsbee (1999) and Saez (2004) challenged the findings of Lindsey and Feldstein. Goolsbee (1999) estimated taxable income elasticities with respect to the top marginal tax rate for several different time periods in the US, which range from 0.0 to 0.7 . He showed therefore that even if tax rates increase, tax revenue will still increase. Saez (2004) calculated long-term elasticities of the top $1 \%$ income share with respect to the top marginal tax rate which were less than one. His findings did not show evidence of the Laffer curve.

The present study aims to further enhance the research on the existence of the arithmetic and economic effect of the taxation regimes in state revenues. Additionally, it will try to prove the existence of the Laffer curve in various countries. Finally, another contribution of this research is the cluster analysis of the countries with similar tax regimes and economic levels. The existence of the Laffer curve in a global scale will provide grounding of the inefficiency of centralized economies, where the economic activity is heavily funded from tax revenues.

The paper is organized as follows: Section 2 presents the different equation models of tax revenue. Section 3 describes the tax data which were used for the econometric 
estimation of the different models. Section 4 describes the estimation results for three categories a) corporate tax, b) overall personal and corporate tax and c) personal tax. Section 5 presents the similarities of tax regimes among the OECD countries included in the analysis.

\section{Different Equation Models for Tax Revenue}

The research tries to identify which type of equation best describes how tax revenue is generated, both for personal income and corporate income tax. In order to estimate the best equation, three equation models with different specifications are fitted in the sample. The sample of data consists of different countries and periods. Tax revenue can be considered to be linear correlated with the tax rate:

$T=b_{1} * \tau$

Each country has a different tax base and it can be referred that the tax base is associated with the wealth levels of the country. The relationship between the effective tax rate, the wealth levels of the country and the tax base is summarized by the following identity, developed with the DuPont formula (OECD, 2017):

$\frac{T}{G D P}=\frac{T}{B} * \frac{B}{G D P}$

Tax revenue as a percentage of GDP is determined by two ratios: tax revenue T over the tax base B and tax base B over GDP. Isolating the first term of equation (2), equation (1) can be transformed in the following linear correlation function, where the tax revenue is expressed as a percentage of GDP and linear related with a tax rate, which shifts depending on each country's policy:

$\left(\frac{T}{G D P}\right)_{i t}=b_{0 i}+b_{1} * \tau_{i t}+\varepsilon_{i t}$

Where the subscripts $\mathrm{i}$ and $\mathrm{t}$ correspond to country and year, $\mathrm{b}_{0 i}$ represents the country fixed effects describing the country-specific tax conditions, $\tau_{i t}$ is the tax rate and $\varepsilon_{i t}$ is the error term. A positive relationship of the tax revenue (as a percentage of GDP) and the tax rate is expected.

Returning back to equation (2), we proceed by considering the parabolic form, through which we introduce in our analysis the findings of Laffer's theory. The first ratio corresponds to the effective marginal tax rate $\tau$, i.e., the rate that transforms the tax base into revenue from taxes, i.e.:

$\tau=\frac{T}{B}$ 
There are two channels through which the increase in the effective tax rate affects tax revenues:

$>$ The change in the tax rate times the given tax base, which is positive. This is the Laffer's arithmetic effect;

$>$ The indirect effect of the change in the tax rate on the tax base, which is expected to be negative. This is the Laffer's economic effect;

As a result, the overall effect of a change in the tax rate on the relevant tax revenue is ambiguous and depends on whether the arithmetic or the economic effect will prevail.

Laffer's economic effect can be described as a function relating the size of the tax base with the level of the tax rate as follows:

$\mathrm{B}=b_{1}+b_{2} * \tau$

Where $b_{1}$ represents the tax free income threshold and $b_{2}$ represents the marginal effect of the tax rate on the tax base, which according to Laffer's theory, is expected to be negative, given that increased tax rates reduce the incentives to work, invest, save and consume. This concept expressed by Laffer (2004) is as in Feldstein's (1995) elasticity of taxable income.

Substituting this expression into equation (4) we derive the following equation 6 :

$$
\frac{T}{G D P}=\left[\frac{T}{B}\right] *\left[\frac{B}{G D P}\right]=\tau *\left(b_{1}+b_{2} * \tau\right)=b_{1} * \tau+b_{2} * \tau^{2}
$$

Finally, we add a fixed term for the shifts in tax regimes of each country, as well as an error term as in equation 7 :

$$
(T / G D P)_{i t}=b_{0 i}+b_{1} * \tau+b_{2} * \tau^{2}+\varepsilon_{i t}
$$

Where the subscripts $\mathrm{i}$ and $\mathrm{t}$ correspond to country and year, $\mathrm{b}_{0 i}$ represents the country fixed effects describing the country-specific tax conditions, $\tau_{i t}$ is the tax rate and $\varepsilon_{i t}$ is the error term. The $b_{0}$ coefficient is of extreme importance, describing the government's ability to increase tax revenues in each country, which may depend on the institutional framework and other country-specific socio-economic characteristics. The coefficient $b_{1}$ is expected to have a positive sign, indicating a positive relationship of the tax revenue (as a percentage of GDP) and the tax rate. The coefficient $b_{2}$ is expected to have a negative sign, indicating a negative relationship of the tax revenue and the square of the tax rate, so that the parabola curve has an inverted $U$ shape, resembling the Laffer Curve. The turning point above which tax revenues will decrease when tax rates rise further gives the effective marginal tax rate. The turning point is presented in equation 8 : 
$\tau^{*}=-\frac{b_{0}}{2 * b_{1}}$

The last equation which can considered is a the hyperbolic function where successive increases in tax rates generate smaller and smaller tax revenues increases, with the latter never falling and is expressed by the following equation 9 and in Ln form as in equation 10:

$\left(\frac{T}{G D P}\right)_{i t}=b_{0 i}+\left(\frac{b_{1} * \tau_{i t}}{1+b_{2} * \tau_{i t}}\right)+\varepsilon_{i t}$

$\operatorname{Ln}\left(\frac{T}{G D P}\right)_{i t}=b_{0 i}+b_{1} * \ln \left(\tau_{i t}\right)+b_{2} * \ln \left(\frac{1}{1+\tau_{i t}}\right)+\varepsilon_{i t}$

In its simplest form, the equation 10 becomes:

$(T / G D P)_{i t}=\mathrm{b}_{0 i}+\mathrm{b}_{1^{*}}\left(1 / \tau_{i t}\right)+\varepsilon_{i \mathrm{t}}$

The coefficient $b_{1}$ is expected to have a negative sign, indicating a negative relationship between the tax revenue (as a percentage of GDP) and the ratio $1 /$ tax rate. In this functional form, $\left(b_{0 i}-b_{1}\right)$ approaches the maximum tax revenue per country with the second term always reducing it. In the extreme case where the tax rate is $100 \%$, the tax revenue is identical with the above difference but never falls.

Our sample consists of multiple entities and variables at multiple time periods. Taxation policy among countries differs and there exist outliers from the changes in taxation policy, which might have cross borders effects. For the Linear form and Parabolic equations the panel least squares methodology is used to test the sample. For the polynomial or parabolic form of the equation, estimated generalized least squares is considered appropriate with a cross section weighting in the sample. Panel cross section weights are eliminating sub-populations differences attribute to the wealth standard of each country.

\section{Description of the Dataset}

The analysis covers 31 OECD countries over the period 2000-2016. For corporate income tax, 26 OECD countries were included in the analysis, due to lack of data. Tax revenues are expressed as a percentage of GDP, as these indicators provide a standard way to compare tax levels across countries and over time. The main source for the data on tax revenues is the OECD Revenue Statistics Database, which provides detailed and internationally comparable tax data for all OECD countries from 1955 onwards.

Specifically, data on corporate income tax revenues as a percentage of GDP were extracted from sub-heading 1210 'Taxes on Profits of Corporates'. Personal income tax revenues as a percentage of GDP are derived by adding data included in the 
following subheadings 1110 'Taxes on Income, Profits and Capital Gains of Individuals', 2100‘ Employees Social Security Contributions,' and 3000 'Taxes on Payroll and Workforce'. The annual OECD Taxing Wages publication shows average and marginal effective tax rates for eight different household types, which vary by income level and household composition (single persons, single parents, one or two earners, couples with or without children). The effective all-in average tax rate is the total tax burden on personal income, calculated by the sum of personal income tax and employee social security contributions expressed as a percentage of gross wage earnings.

The PIT analysis in the paper uses indicators of all -in average tax rate for single individuals earning $100 \%$ of the average wage for the sake of simplicity. Including families would not bring much information (Akgun et al., 2017). Data on the corporate tax rate (CIT) on distributed profits are derived from the OECD Tax Database, where the combined central and sub central statutory tax rates are reported. Also, in the same Tax Database OECD calculations based on country information on the taxation of dividends provide data on the overall PIT and CIT rate on dividends.

\section{Empirical Results}

\subsection{Corporate Income Tax}

The results of estimating the effect of the CIT rate on corporate income tax revenue are summarized in the following Table 1:

Table 1. Taxes on profits of corporations - Corporate income tax

\begin{tabular}{|c|c|c|c|c|c|c|}
\hline $\begin{array}{l}\text { Dependent } \\
\text { Variable: Taxes on } \\
\text { profits of } \\
\text { corporations }\end{array}$ & (1) & (2) & (3) & (4) & (5) & (6) \\
\hline $\mathrm{C}$ & $\begin{array}{l}2.229 * * * \\
(0.368)\end{array}$ & $\begin{array}{l}-2.640^{*} \\
(1.125) \\
\end{array}$ & $\begin{array}{l}40.56 * * * \\
(0.294) \\
\end{array}$ & $\begin{array}{l}2.213 * * * \\
(0.152)\end{array}$ & $\begin{array}{l}0.894 \\
(0.510)\end{array}$ & $\begin{array}{l}40.37 * * * \\
(0.139) \\
\end{array}$ \\
\hline $\begin{array}{l}\text { CIT rate on } \\
\text { distributed profits }\end{array}$ & $\begin{array}{l}0.032 * \\
(0.013)\end{array}$ & $\begin{array}{l}0.399 * * * \\
(0.081)\end{array}$ & & $\begin{array}{l}0.032 * * * \\
(0.005)\end{array}$ & $\begin{array}{l}0.128 * * * \\
(0.036)\end{array}$ & \\
\hline CIT rate squared & & $\begin{array}{l}-0.007 * * * \\
(0.001)\end{array}$ & & & $\begin{array}{l}-0.002 * * \\
(0.001)\end{array}$ & \\
\hline $1 / \mathrm{CIT}$ rate & & & $\begin{array}{l}-2.4678 * * \\
(0.7542)\end{array}$ & & & $\begin{array}{l}-2.4186^{* * * *} \\
(3.689)\end{array}$ \\
\hline Method & $\begin{array}{l}\text { Panel } \\
\text { Least } \\
\text { Squares }\end{array}$ & $\begin{array}{l}\text { Panel } \\
\text { Least } \\
\text { Squares }\end{array}$ & $\begin{array}{l}\text { Panel } \\
\text { Least } \\
\text { Squares }\end{array}$ & $\begin{array}{l}\text { Panel } \\
\text { EGLS }\end{array}$ & $\begin{array}{l}\text { Panel } \\
\text { EGLS }\end{array}$ & $\begin{array}{l}\text { Panel } \\
\text { EGLS }\end{array}$ \\
\hline Observations & 440 & 440 & 440 & 440 & 440 & 440 \\
\hline $\begin{array}{l}\text { Cross - sections } \\
\text { included }\end{array}$ & 26 & 26 & 26 & 26 & 26 & 26 \\
\hline R-squared & 0.014 & 0.059 & 0.023 & 0.853 & 0.863 & 0.861 \\
\hline R-squared adjusted & 0.012 & 0.055 & 0.022 & 0.843 & 0.854 & 0.853 \\
\hline
\end{tabular}




\begin{tabular}{|l|l|l|l|l|l|l|} 
F-Statistic & 6.300 & 13.729 & 10.706 & 92.025 & 96.504 & 98.713 \\
\hline $\begin{array}{l}\text { Country Fixed } \\
\text { Effects }\end{array}$ & NO & NO & NO & YES & YES & YES \\
\hline Year Fixed Effects & NO & NO & NO & NO & NO & NO \\
\hline Standard Error & 1.711 & 1.673 & 1.702 & 0.685 & 0.684 & 0.685 \\
\hline
\end{tabular}

The Panel Least Squares estimation method assumes that there is neither significant country nor significant temporal effects. Even though in the estimation results, the coefficients in all three equations have the expected signs, the fit of data in the equations have very low value, close to zero, indicating that a very small percentage of the total variation in Corporate Tax Revenues is explained by the model.

The Estimated Generalized Least Squares method is considered appropriate with a cross section weighting in the sample, as subpopulation differences attributed to the wealth standard of each country are eliminated. The introduction of the additional term in the simple model provides additional predictive power in the model. The adjusted R- squared of the equation increased by 1 percent. The coefficient of the CIT rate has the expected positive sign and the coefficient of the CIT rate squared has the expected negative sign, both being statistically significant at 0.001 and 0.05 levels.

In model (6), the adjusted R- squared slightly falls compared to model (5). Also the coefficient of the $1 /$ CIT rate variable has the expected sign, though its magnitude draws our attention and will be explored further with the progress of our research. As a conclusion, the non-monotonic relationship between the tax rate and the relevant tax revenue is confirmed and is in line with the Laffer curve theory.

The average asymptotic rate equals the difference of the average intercept and the coefficient of the variable (1/CIT). In both models (3) and (6) it takes the value of approximately $37.95 \%$. In the parabolic form of equation in model (2), the intercept has no economic meaning as it has a negative sign, a problem which is dealt with in model (5), where the Panel EGLS method is used. The effective tax rate after the conversion of the estimated coefficients into percentages equals $34.9 \%$. Comparing the average asymptotic rate with the effective tax rate, we come to the conclusion that if in an economy there are no opportunities for tax evasion, the effective tax rate will be moving towards the asymptotic rate, though this conclusion needs to be further investigated.

\subsection{Overall Personal and Corporate Income Tax}

If we regress the corporate tax revenues against the overall personal and corporate tax rate on distributed dividends, we derive the following results as shown in Table 2. Again the adjusted R-squared values are very low with the Panel Least Squares Estimation method, suggesting that the Estimated Generalized Least Squared method is more appropriate. 
In model (4) the coefficient of overall PIT and CIT rate is not statistically significant at $0.5 \%$ level and does not have the expected positive sign. In model (5) the adjusted R-squared falls, penalizing the introduction of the extra variable in the model. Again, the estimated coefficients are not statistically significant at $0.5 \%$ level.

Table 2. Taxes on profits of corporations - Overall Personal and Income Tax

\begin{tabular}{|c|c|c|c|c|c|c|}
\hline $\begin{array}{l}\text { Dependent Variable: } \\
\text { Taxes on profits of } \\
\text { corporations }\end{array}$ & (1) & (2) & (3) & (4) & (5) & (6) \\
\hline $\mathrm{C}$ & $\begin{array}{l}3.082 * * * \\
(0.407)\end{array}$ & $\begin{array}{l}-2.345^{*} \\
(0.189)\end{array}$ & $\begin{array}{l}37.61 * * * \\
(0.318)\end{array}$ & $\begin{array}{l}3.147 * * * \\
(0.128)\end{array}$ & $\begin{array}{l}2.131 * * * \\
(2.131)\end{array}$ & $\begin{array}{l}32.26 * * \\
*(0.134)\end{array}$ \\
\hline $\begin{array}{l}\text { Overall PIT and CIT } \\
\text { rate }\end{array}$ & $\begin{array}{l}0.001 \\
(0.009)\end{array}$ & $\begin{array}{l}0.260 * * * \\
(0.054)\end{array}$ & & $\begin{array}{l}-0.000 \\
(0.003)\end{array}$ & $\begin{array}{l}0.043 \\
(0.026)\end{array}$ & \\
\hline $\begin{array}{l}\text { Overal PIT and CIT } \\
\text { rate squared }\end{array}$ & & $\begin{array}{l}-0.003^{* * * *} \\
(0.000)\end{array}$ & & & $\begin{array}{l}-0.004 \\
(0.000)\end{array}$ & \\
\hline $\begin{array}{l}\text { 1/overall PIT and CIT } \\
\text { rate }\end{array}$ & & & $\begin{array}{l}-2.7178^{* *} \\
(1.3276)\end{array}$ & & & $\begin{array}{l}-0,4091^{*} \\
(0.5723)\end{array}$ \\
\hline Method & $\begin{array}{l}\text { Panel } \\
\text { Least } \\
\text { Squares }\end{array}$ & $\begin{array}{l}\text { Panel } \\
\text { Least } \\
\text { Squares }\end{array}$ & $\begin{array}{l}\text { Panel } \\
\text { Least } \\
\text { Squares }\end{array}$ & $\begin{array}{l}\text { Panel } \\
\text { EGLS }\end{array}$ & $\begin{array}{l}\text { Panel } \\
\text { EGLS }\end{array}$ & $\begin{array}{l}\text { Panel } \\
\text { EGLS }\end{array}$ \\
\hline Observations & 440 & 440 & 440 & 440 & 440 & 440 \\
\hline $\begin{array}{l}\text { Cross - sections } \\
\text { included }\end{array}$ & 26 & 26 & 26 & 26 & 26 & 26 \\
\hline R-squared & 0 & 0.051 & 0.009 & 0.843 & 0.839 & 0.842 \\
\hline R-squared adjusted & -0.002 & 0.047 & 0.007 & 0.833 & 0.829 & 0.832 \\
\hline F-Statistic & 0.015 & 11.725 & 4.191 & 85.414 & 79.987 & 84.334 \\
\hline Country Fixed Effects & NO & $\mathrm{NO}$ & $\mathrm{NO}$ & YES & YES & YES \\
\hline Year Fixed Effects & NO & $\mathrm{NO}$ & NO & NO & $\mathrm{NO}$ & $\mathrm{NO}$ \\
\hline Standard Error & 1.723 & 1.681 & 1.715 & 0.714 & 0.709 & 0.712 \\
\hline
\end{tabular}

In model (6), the R-squared value suggests that this model fits best. Also, the estimated coefficient has the expected negative sign of the hyperbolic function and is statistically significant at $0.5 \%$ level. The Laffer curve cannot be supported with the results of the parabolic specification. The hyperbolic equation proves to be more appropriate to describe the results. The observations made in section 5.1 are also valid in this section. Though, when the dividends tax is added to the corporate income tax rate and given the different tax treatment of dividends in OECD countries and the complexity of this tax, as it can be subject to personal income tax also, the analysis becomes rather ambiguous and further exploration is needed.

\subsection{Personal Income Tax}

If we regress the property tax revenues against the All-in Average PIT, we derive the following results as shown in Table 3. Similarly as before, models (1), (2) and (3) which use the Panel Least Squares estimation method, have very low R squared values. In model (2), the coefficient of the all-in PIT rate squared does not have the expected negative sign. In model (3), the coefficient has the expected negative sign but again its magnitude needs further investigation as we progress in our research. 
When Panel EGLS estimation method is used, the adjusted R-squared increases with the introduction of an extra variable in model (5). Both estimated coefficients are statistically significant at $0.01 \%$ level. The all-in average rate which maximizes personal income tax revenues is estimated at $44 \%$.

Table 3. Personal Income Tax Revenues - All in average Tax Rate

\begin{tabular}{|c|c|c|c|c|c|c|}
\hline $\begin{array}{l}\text { Dependent } \\
\text { Variable: } \\
\text { Personal } \\
\text { Income Tax } \\
\text { Revenue }\end{array}$ & (1) & (2) & (3) & (4) & (5) & (6) \\
\hline $\mathrm{C}$ & $\begin{array}{l}2.299 * * * \\
(0.539)\end{array}$ & $\begin{array}{l}3.264^{*} \\
(1.568)\end{array}$ & $\begin{array}{l}19.386 * * * \\
(0.489)\end{array}$ & $\begin{array}{l}4.705 * * * \\
(0.448)\end{array}$ & $\begin{array}{l}-0.369 \\
(0.612)\end{array}$ & $\begin{array}{l}16.261 * * * \\
(0.311)\end{array}$ \\
\hline $\begin{array}{l}\text { All-in Average } \\
\text { PIT Rate }\end{array}$ & $\begin{array}{l}0.369 * * * \\
(0.019)\end{array}$ & $\begin{array}{l}0.294^{*} \\
(0.116)\end{array}$ & & $\begin{array}{l}0.278 * * * \\
(0.016)\end{array}$ & $\begin{array}{l}0.704 * * * \\
(0.049)\end{array}$ & \\
\hline $\begin{array}{l}\text { All-in Rate } \\
\text { Squared }\end{array}$ & & $\begin{array}{l}0.001 \\
(0.002)\end{array}$ & & & $\begin{array}{l}-0.008 * * * \\
(0.001)\end{array}$ & \\
\hline 1/All-in Rate & & & $\begin{array}{l}-1.7794 * * * \\
(0.11345) \\
\end{array}$ & & & $\begin{array}{l}-1.018 * * * \\
(0,7566) \\
\end{array}$ \\
\hline Method & $\begin{array}{l}\text { Panel } \\
\text { Least } \\
\text { Squares }\end{array}$ & $\begin{array}{l}\text { Panel } \\
\text { Least } \\
\text { Squares }\end{array}$ & $\begin{array}{l}\text { Panel Least } \\
\text { Squares }\end{array}$ & $\begin{array}{l}\text { Panel } \\
\text { EGLS }\end{array}$ & $\begin{array}{l}\text { Panel } \\
\text { EGLS }\end{array}$ & Panel EGLS \\
\hline Observations & 523 & 523 & 523 & 523 & 523 & 523 \\
\hline $\begin{array}{l}\text { Cross - } \\
\text { sections } \\
\text { included }\end{array}$ & 31 & 31 & 31 & 31 & 31 & 31 \\
\hline R-squared & 0.404 & 0.405 & 0.32 & 0.979 & 0.982 & 0.979 \\
\hline $\begin{array}{l}\text { R-squared } \\
\text { adjusted }\end{array}$ & 0.403 & 0.402 & 0.319 & 0.978 & 0.981 & 0.978 \\
\hline F-Statistic & 354.200 & 177.148 & 245.999 & 737.164 & 837.826 & 765.246 \\
\hline $\begin{array}{l}\text { Country Fixed } \\
\text { Effects }\end{array}$ & $\mathrm{NO}$ & $\mathrm{NO}$ & $\mathrm{NO}$ & YES & YES & YES \\
\hline $\begin{array}{l}\text { Year Fixed } \\
\text { Effects }\end{array}$ & $\mathrm{NO}$ & $\mathrm{NO}$ & NO & NO & NO & $\mathrm{NO}$ \\
\hline Standard Error & 3.244 & 3.246 & 3.466 & 0.723 & 0.698 & 0.729 \\
\hline
\end{tabular}

The observations made above regarding corporate income tax are valid also for the personal income tax. We should note though, that in model (5) the average intercept has a negative sign, suggesting a great degree of differentiation regarding the calculation method, the schedule and the tax habits among the OECD countries included in our analysis.

\section{Tax Similarities among OECD countries}

\subsection{Personal Tax}

The groups of countries with similarities regarding the personal tax burden are presented in the following Table 4. 
According to the above Table 4, we can argue that the fixed coefficient per country describes the tax regime. In order to further strengthen this argument, a further examination of the various tax regimes country's specific characteristics should be examined, which will be done in a future work.

Table 4. Similarities regarding the personal tax

\begin{tabular}{|c|c|c|c|c|c|c|c|c|c|}
\hline \multicolumn{2}{|c|}{ 1st Group } & \multicolumn{2}{|c|}{ 2nd Group } & \multicolumn{2}{|c|}{ 3nd Group } & \multicolumn{2}{|l|}{ 4th Group } & \multicolumn{2}{|c|}{ 5th Group } \\
\hline Country & $\begin{array}{l}\text { Cr.fixe } \\
\text { d }\end{array}$ & Country & $\begin{array}{l}\text { Cr.fixe } \\
\text { d }\end{array}$ & Country & $\begin{array}{l}\text { Cr.fixe } \\
\text { d }\end{array}$ & Country & $\begin{array}{l}\text { Cr.fixe } \\
\text { d }\end{array}$ & Country & $\begin{array}{l}\text { Cr.fixe } \\
\text { d }\end{array}$ \\
\hline Turkey & $-6,887$ & Greece & $-2,078$ & Japan & $-0,897$ & Netherlands & 0,019 & $\begin{array}{l}\text { Switzerla } \\
\text { nd }\end{array}$ & 2,141 \\
\hline $\begin{array}{l}\text { Slovak } \\
\text { Republic }\end{array}$ & $-5,151$ & Portugal & $-2,056$ & Korea & $-0,864$ & Germany & 0,344 & Belgium & 2,204 \\
\hline $\begin{array}{l}\text { Czech } \\
\text { Republic }\end{array}$ & $-4,482$ & Spain & $-2,016$ & $\begin{array}{l}\text { United } \\
\text { Kingdom }\end{array}$ & $-0,434$ & $\begin{array}{l}\text { United } \\
\text { States } \\
\end{array}$ & 0,424 & Canada & 2,551 \\
\hline Estonia & $-4,151$ & & & Slovenia & $-0,312$ & Ireland & 0,683 & $\begin{array}{l}\text { New } \\
\text { Zealand } \\
\end{array}$ & 3,261 \\
\hline Hungary & $-3,477$ & & & $\begin{array}{l}\text { Luxembo } \\
\text { urg }\end{array}$ & $-0,282$ & Australia & 0,803 & Austria & 4,121 \\
\hline Poland & $-3,043$ & & & Italy & $-0,237$ & Israel & 1,056 & Sweden & 6,521 \\
\hline & & & & Norway & $-0,195$ & Finland & 1,863 & Denmark & 10,301 \\
\hline & & & & France & $-0,035$ & & & & \\
\hline
\end{tabular}

\section{Conclusions}

The present study tried to investigate the relationship between the tax rate and the relevant tax revenue, an issue that receives a lot of attention within the academic and political community. We explored both theoretically and empirically, with the estimation of three possible forms of the relation of revenue and taxes; the linear, the parabolic and the asymptotic hyperbolic. The data sample was treated as a panel data and pool data in order to isolate the country specific characteristic of the tax regimes.

What is innovative in our approach, apart from the development of the three functional forms, is the introduction of the country fixed effects as a variable, which represents the different tax regimes as well as countries' specificities in tax collection, compared to previous researchers who add explanatory variables in their models. Results suggest that the introduction of multiple variables, which are used as proxies of socio economic conditions of a country, do not provide sustainable results. There is strong evidence that there are other proxies, which cannot be specified and easily obtained. However, these "unknown" proxies are important for the specification of the relation between tax revenues and tax rates.

We conclude among others that there is a high differentiation between tax regimes and tax morale in different countries. Countries with low tax morale show a negative 
cross-sectional intercept. We also have key indications that tax evasion as well as the opportunities to evade taxes create Laffer's parabolic phenomenon. When opportunities for tax evasion are reduced, the mathematical relationship between tax revenue and the tax rate is transformed into an asymptotic hyperbola. The limit is the maximum tax rate, beyond which the revenue does not increase further, neither declines, creating fiscal crises which affect variables such as GDP decline and increasing unemployment rate. We will attempt to explore this issue in our future research.

The contribution of the current research, apart from exploring how tax revenue is generated, lies in the fact that tax policy within a country should be directed towards actions that will in the first place switch the existing fixed cross-sectional term from negative to positive. Also, if tax evasion gives its place to tax morale then the tax rate is actually transformed into a real fiscal policy tool without creating budgetary problems.

\section{References:}

Agell, J., Persson, M. 2001. On the analytics of the dynamic Laffer curve. Journal of Monetary Economics, Vol. 48, No. 2, 397-414.

Akgun, O., Bartolini, D., Cournede, B. 2017. The capacity of Governments to raise taxes. OECD Economics Department, Working Papers, No. 1407.

Atkinson, A.B., Stern, N.H. 1980. Taxation and incentives in the UK. Lloyds Bank Review, 136, 43-46.

Ballard, C.L., Fullerton, D., Shoven, J.B., Whalley, J. 2005. The Relationship between Tax Rates and Government Revenue. In National Bureau of Economic Research, Volume “A General Equilibrium Model for Tax Policy Evaluation”, 188-202.

Brill, A., Hassett, K.A. 2007. Revenue-Maximizing Corporate Income Taxes: The Laffer Curve in OECD Countries. American Enterprise Institute for Public Policy Research, Working paper 137.

Busato, F., Chiarini, B. 2011. Steady state Laffer curve with the underground economy. LUISS Lab of European Economics, Working Document No. 85.

Canto, V.A., Joines, D.H., Laffer, A.B. 1980. Tax Rates, Factor Employment and Market Production. Federal Reserve Bank of St. Louis Review.

Dalamagas, B. 1998. Endogenous growth and the dynamic Laffer curve. Journal of Applied Economics, Vol. 30, Issue 1, 63-75.

Feldstein, M. 1995. The Effect of Marginal Tax Rates on Taxable Income: A Panel Study of the 1986 Tax Reform Act. Journal of Political Economy, 103(3), 551-572.

Fullerton, D. 1982. On the Possibility of an Inverse Relationship between Tax Rates and Government Revenues. Journal of Public Economics, Vol 19, 3-22.

Galanos, Ch., Kantianis, D., Liapis, K., Politis, E. 2014. Quantitative Approach to Measure Tax Competitiveness Between EU Countries. International Journal of Economic Sciences and Applied Research, Volume VII, Issue 3, 7-23.

Goolsbee, A. 1999. Evidence on the High-Income Laffer Curve from Six Decades of Tax Reform. Brookings Papers on Economic Activity, University of Chicago.

Heijman, W.J.M., van Ophem, J.A.C. 2005. Willingness to Pay Tax: the Laffer Curve Revisited for 12 OECD countries. The Journal of Socio-Economics, 714-723.

Hemming, R., Kay, J.A. 1980. The Laffer curve. Fiscal Studies, 1, 83-90. 
Hsing, Y. 1996. Estimating the laffer curve and policy implications. Journal of SocioEconomics, 25(3), 395-401.

Karas, M. 2012. Tax Rate to maximize the revenue: Laffer curve for the Czech Republic. Acta Universitatis Agriculturae et Silviculturae Mendelianae Brunensis, Vol. LX, No 4, 189-194.

Kawano, L., Slemrod, J. 2016. How Do Corporate Tax Bases Change when Corporate Tax Rates Change? With implications for the Tax Rate Elasticity of Corporate Tax Revenues. International Tax and Public Finance, 23(3), 401-433.

Kiefer, D.W. 1978. An economic analysis of the Kemp/Roth tax cut bill H.R. 8333: A description, an examination of its rationale, and estimates of its economic effects. Library of Congress.

Laffer, A.B. 2004. The Laffer curve: past, present, and future. The Heritage Foundation, No, 1765.

Liapis, K., Galanos, Ch. 2010. Accounting GAAPs and accounting treatments for management of property: case studies from Greek real estate market. European Research Studies Journal, 13(3), 169-194. DOI: 10.35808/ersj/292

Liapis, K., Rovolis, A., Galanos, Ch. 2012. Toward a Common Tax Regime for the European Union Countries. European Research Studies Journal, 15(3), 89-108. DOI: $10.35808 / \mathrm{ersj} / 364$

Liapis, K., Rovolis, A., Galanos, Ch. 2014. The Tax Regimes of the EU Countries: Trends, Similarities and Differences. In: Karasavvoglou, A., Polychronidou, P. (eds) Economic Crisis in Europe and the Balkans. Contributions to Economics. Springer, Heidelberg. doi.org/10.1007/978-3-319-00494-5_7

Liapis, K.J., Politis, E.D. 2018. Disclosure of the Laffer economic effect in property valuations to fair value. Journal of Property Investment and Finance, 36(3), 305318.

Lindsey, L.B. 1987. Individual taxpayer response to tax cuts 1982-1984 with implications for the revenue maximizing tax rate. Journal of Public Economics, 33(2), 173-206.

Malcomson, J.M. 1986. Some analytics of the Laffer curve”, Journal of Public Economics, Vol. 29 No. 3, pp.263-279

Mirowski, P., (1982), "What's Wrong with the Laffer Curve? Journal of Economic Issues, $16(3), 815-828$.

Saez, E. 2004. Reported incomes and marginal tax rates, 1960-2000: Evidence and policy implications. Tax Policy and the Economy, MIT Press, 18, 117-174.

Sen, H., Bulut-Cevik, Z.B., Kaya, A. 2017. The Khaldun-Laffer Curve Revisited: A Personal Income Tax-Based Analysis for Turkey. Munich Personal RePEc Archive, Paper No. 78850.

Stuart, C.E. 2018. Swedish Tax Rates, Labor Supply, and Tax Revenues. Journal of Political Econom, 89(5), 1020-1038.

Trabandt, M., Uhlig, H. 2011. The Laffer Curve Revisited. Journal of Monetary Economics, 58, 305-327.

Van Ravestein, A., Vijlbrief, H. 1988. Welfare cost of higher tax rates: An empirical Laffer curve for the Netherlands. De Economist, 136(2), 205-219.

Vogel, L. 2012. Tax Avoidance and Fiscal Limits: Laffer Curves in an Economy with an Informal Sector. European Economy Economic Papers, No. 448.

Vokshi, N.B. 2018. The Connection between Accounting and Taxation from the Perspective of Preparing the Financial Statements. International Journal of Economics \& Business Administration, 6(4), 34-47.

Wanniski, J. 1978. Taxes, Revenues and the 'Laffer Curve'. The Public Interest, 50, 3-16. 